\section{Transnational threats and security in the Americas: patterns, contradictions, and more}

\section{Enrique S. Pumar}

"Man knows himself only in history, never through introspections." Wilhelm Dilthey

$\mathrm{F}$ r students of Latin America, the pattern and historical development of belligerent conflicts in the region is a puzzle worthy of much attention and inquiry. Unlike other developing regions, Latin American has experienced its share of domestic conflicts - revolutions, protest, coups, civil unrests - but fewer interstate conflicts than any other developing region for much of the twentieth century. Moreover, some areas of Latin America seem more prone to domestic upheavals than others. Only in very few instances have domestic issues spilled over into state wars between or among neighboring countries. In the handful of cases when regional issues have instigated disputes, these have been resolved diplomatically without much fanfare.

In addition, political developments in Latin America defy social science research on peace and conflict resolution. The correlation between democracy and peace throughout the region has been spotty at best. The ABC nations - Argentina, Brazil, and Chile - have experienced their share of internal political instability, military authoritarianism, and, like much of the region, a façade of democracy despite their relative potent economies and cultural cosmopolitanism, but no interstate wars. Costa Rica, the only sustainable democracy since 1948, has no armed forces and therefore no commitment or desire to fight any of its neighbors. In countries with a similar political history, such as Venezuela and Colombia, social and transborder tensions have never resulted in war despite the occasional cantankerous public rhetoric. The absence of interstate wars is also evident among other nations with dissimilar political development throughout the hemisphere, regardless of the nature of their polity.

In terms of the correlation between economic development and the prevalence of belligerency, the outcome throughout Latin America is not much different. According to the 2005 Human Development Report, Argentina, Chile, Uruguay, Costa Rica, Cuba, and Mexico top the region in human development indicators. Yet all these nations, with the exception of Costa Rica, suffered from civil strife but not dyadic conflicts in the past five decades. Moreover, the wide development gap between these nations and the rest of the region does not appear to have significant bearing on the propensity to spark conflicts. The per capita GDP difference between traditional rivals Argentina, ranked 34th in the Human Development Index (HDI) in 2005, and Brazil, ranked 63th, is about $\$ 5,000$. Chile's per capita GDP, the second-highest in the region, comes in at about \$2,000 less than Argentina's. But Haiti and Guatemala, with the lowest HDIs in the region, had a combined 2005 per capita GDP that amounted to half of Argentina's. ${ }^{1}$ Despite this skewed development distribution and tensions along their borders, all these nations had one or another form of domestic political instability but no dyadic conflicts. More significantly, their domestic strife has not led to war with neighbors.

This article examines recent political and economic developments in Latin America and lays out a framework of analysis that might explain the paradoxical manifestation of conflicts in the region, namely, that while Latin America has experienced its share of intrastate violence, the region is one of the most peaceful in the developing world in terms of interstate violence. The principal aim is to explain the relative interstate peace in Latin America for most of the twentieth century. Unlike other developing regions, the region witnessed just two cases when Latin nations have fought each other since the Chaco War of $1932 .^{2}$ Neither conflict lasted more than a year and neither escalated into an all-out regional conflict. Following a within-case comparative approach, ${ }^{3}$ I suggest that interstate peace in Latin America parallels the explosion of transnational relations, especially pertaining to transnational securityrelated issues, throughout the region. I propose, therefore, that transnationalism has fostered interstate peace in the region through three specific mechanisms often neglected in the peace literature. First, transnational relations require policy coordination regimes where nations, even those who perceive themselves as rivals or adversaries, cooperate. Second, nations engaged in transnationalism quickly realize the spillover effects of transborder problems; consequently, actors become aware that to solve one contentious issue they must collaborate on an array of other broader issues as well. ${ }^{4}$ Issue-linkage makes political coordination and collaboration not only possible but also indispensable among even rival nations. Third, the perception of transnational threats creates a common enemy that prioritizes the formation of coordinating conjunctions to handle such threats. The perception of a shared menacing threat prioritizes the desire for confederation among nations because, as Thomas Hobbes unequivocally notes, all men have a desire for preservation and sovereignty that connotes the tacit expectation that if men cannot defend themselves, rulers will defend citizens. ${ }^{5}$

In particular, I argue that the rise of transnational, multidimensional threats diverts attention from other points of contention governing interstate relations and gears decisionmakers to the imminent task of devising mechanisms to prevent or control the dangers posed by non-state actors. In all, these three dimensions of the transnational process sustain the basis for a security regime that has been embedded in the politica culture of the region for years but was later institutionalized through various conventions with the outbreak of the Cold War. Hence, hemispheric diplomatic norms reward regional cooperation and nonbelligerent resolutions of disputes.

I proceed in three stages. First, I review micro and macro perspectives of the peace studies literature to show how major individualist paradigms come short of explaining 
the relative peace that reigns in Latin America during the postwar years. I then argue that recent middle-range explanations for interstate peace do not fare well when confronted with the evidence from Latin America. This is particularly the case with the arguments associated with the "democratic peace" and "peace through trade" perspectives discussed in a recent paper by Polachek and Seiglie. ${ }^{6}$ The purpose of this discussion is not to test theories or their specific applicability per se but rather to argue that these two positions in particular seem to explain a number of domestic crises but not the peculiar absence of external crises throughout the region. Finally, in the third part of the paper, I propose a framework of analysis that incorporates the effects of transnationalism. Not only has the transnational dimension of peace in Latin America been neglected by contending positions in this literature but also, following this approach, I hope to add new twists to the peace and transnational relations debate in Latin American studies. Actors operate in a social context that gives meaning to their actions.

\section{Micro and macro peace studies and Latin America}

In recent decades, the literature on peace and conflict resolution has turned from the individual to the macro and more recently to the meso level of analysis. ${ }^{7}$ Influenced by Freudian developments in psychology and by the rise of totalitarianism in Europe during the interwar period, the micro level first attributed the nature of conflict to innate aggressive behavior, especially the desire to monopolize and maintain power among leaders with autocratic, dogmatic, and narcissistic personalities. World leaders such as Nasser manifest a propensity for violence as a means to achieve their status and political ambitions. Anthropologists soon followed, emphasizing the role of culture in determining belligerence. ${ }^{8}$ The parable of the tribe argument, for instance, envisions the struggle for power as an inevitable outcome in the course of civilization development. Once culture rewards power and aggressive individual instincts, the social environment fuels a disposition for violent drives. Critics soon dismissed these claims on a number of grounds. One essential criticism of the psychological and cultural positions is the failure to differentiate when aggressive behavior leads to war and when it does not. For if wars result from human aggressiveness and culture alone, would not most societies always be in some sort of Hobbesian state of nature?

Another turn in the psychological movement was popularized during the 1960s when international-relations scholars produced multiple studies on such instrumental questions as the nature of perception, misperception, belief systems, and the operational code of chief policymakers. One pointed insight from this literature is the assertion that cognition is a mediating mechanism between environmental stimuli and individual action. Ideologies and belief systems, for instance, were conceived as filters to interpret social tensions and determine whether specific tenuous conditions merit belligerent action. ${ }^{9}$ What this means for peace studies is certain: misperceptions could escalate interstate conflicts into wars even in situations where aggression is not merited. This behavioralist movement is too burgeoning to discuss in detail here; it suffices to say that through methodological rigor, proponents of the psychological perspective managed to draw attention to the risks associated with actors' socia construction of reality - a topic not always well conceived by proponents of voluntary persuasions. A more profound methodological challenge, of course, is to assess the validity of misperception in light of the self-reporting and interpretative mechanisms usually associated with this body of literature.

A third approach to peace studies emphasizes evolutionary strategic interactions among actors and the calculations behind the desire to go to war or avoid wars altogether. Game theory, the most popular trend from this approach, assumes that decisionmakers are capable of making calculated decisions and that these actors are also utility maximizers. ${ }^{10}$ Game theorists often assert that cooperation is possible when players forfeit the highest payoff in strategic interactions or when interactions among players with limited rationality occur in incremental rounds of the game. In the latter case, landscape theory proposes that social learning resulting from incremental interactions reduces ambiguities and uncertainties and decreases negotiating costs and the utility of side payments under uncertain payoff structures to induce players to cooperate. $^{11}$

Finally, a radically different approach to war and peace derives from the effects of the macro-structural configurations of world politics on state actors. This holistic approach popularized by Waltz, Gilpin, and Modelski among others, asserts that the anarchic nature of international relations fosters conditions under which bouts of war might emerge among states. ${ }^{12}$ According to these scholars, the constellation of power among superpowers as well as their hegemonic capability determines the extent to which peace is possible. Under conditions of anarchy, when a global power is declining, or in multipolar situations, the likelihood of interstate wars seems higher than under other conditions.

Despite the parsimonious insights from both the micro and macro perspectives, these do not seem to have much relevance in understanding the long peace that has reigned in Latin America since the 1932 Chaco War. For one, all of these perspectives assume that threats come from other states with easily definable territorial borders, standing armies, and distinguishable national symbols. In Latin America, as I argue below, for much of the twentieth century the perceived threat derives from transnational non-state actors, such as insurgencies, terrorists, and drug traffickers, that engaged in protracted struggles markedly different in nature and character from the conventional wars these theories attempt to explain. More significantly, Latin nations do not have the same capabilities as industrial nations; consequently, the payoff structure of military calculations is substantially narrower. And when miscalculations take place, these are not as consequential as when superpowers misjudge a potential adversary's intentions. This may be one of the most important reasons that misperceptions rarely lead to war and the culture of power in the region is channeled to cross-national issues and actors. 
In fact, many would argue that one of the implications of the relative economic dependency of developing nations is that this situation constrains the weighting of choices and sovereignty of the state among developing nations and thus reduces incumbent options available to decisionmakers. ${ }^{13}$ Latin American nations also have to contend with the interests of the United States, their most important benefactor, to avoid and contain any dyadic conflicts that may impair regional development and investment efforts as well as good governance schemes. U.S. national security priorities call for a hemisphere free of interstate conflicts that might entangle American armed forces defending the southern flank of the United States, leaving the military vulnerable elsewhere in the world. Finally, counterinsurgency programs launched by the United States since the 1960s devised numerous mechanisms to promote interstate military cooperation against domestic threats. In fact, the evidence from Latin America demonstrates how the disproportionate allocation of resources to handle transnational threats reduces the provability of dyadic compulsions. As the president of Colombia has unequivocally stated to explain the need for Plan Colombia:

The traffic in illicit drugs is clearly a transnational and complex threat, destructive to all our societies, with enormous consequences for those who consume this poison, and enormous effects from the violence and corruption fed by the immense revenues the drug trade generates. The solution will never come from finger-pointing by either producer or consumer countries. Our own national efforts will not be enough unless they are part of a truly international alliance against illegal drugs. ${ }^{14}$

\section{Middle-range theorizing}

A more promising approach for understanding Latin America's long peace derives from the "democratic peace" and the "peace through trade" perspectives. Since all nation-states engage in trade and, regardless of their security capabilities or position in the hierarchical structure of global politics, have a chance at democratic politics, in principle these two meso-level paradigms exhibit potential explanatory powers to decipher the nature of peace among developing nations. Moreover, it is usually the case with democracies that trade and peace occur concurrently at specific historical conjunctures; therefore it is easy to associate a correlation among these three distinct processes.

According to a prominent scholar, the democratic peace perspective rests on four sine qua non assumptions. ${ }^{15}$ First, since the political elite in democratically organized political systems are under certain restraints, namely with regard to transparency and popular accountability, democracies tend to be more peaceful than other forms of political organizations. Second, in part because of the reasons just stated, democracies are less likely to initially use lethal force against other democracies. Furthermore, the relatively peaceful nature of democracies is a political question rather than one caused exclusively by economic conditions or geographical location. And third, democracies are more likely to wage wars toward autocratically governed states than toward other democracies. All-in-all, according to this line of reasoning, polyarchies are more peaceful than any other form of political organization.

In Latin America, the evidence supporting the democratic peace thesis is mixed at best since both democracies and nondemocratic state actors rarely fight each other; of the two cases of interstate conflicts since the 1930s, one involved two democracies (the Peruvian-Ecuadorian territorial disputes), the other a pair of nondemocratic regimes (the El Salvador-Honduras 1969 conflict). More significantly, the waves of military coups through Latin America between 1964 and the mid-1980s did not alter the pattern of regional peace. The return of competitive politics since the late 1980s has also been accompanied by regional peace but there is no evidence to suggest that democracy was the cause. Besides the 1995 border skirmish between Ecuador and Peru, two countries governed by popularly elected leaders at the time, none of the other twenty-one interstate disputes occurring during the decade of the 1990 s resulted in an outbreak of war regardless of the political nature of the regimes or the degrees of democratic manifestations. Likewise, only one dispute, the 1969 "soccer war" between Honduras and El Salvador, resulted in a brief war during the prior three decades, when Latin America witnessed a breakdown of one democracy after another. ${ }^{16}$

Perhaps one reason for this wavering evidence lies in the nature of democracies that we witness throughout Latin America. In the region, almost all democracies, particularly early ones, are organized around very strong presidential systems where the executive branch enjoys relative autonomy. For instance, it has been suggested that the rare number of electoral primaries facilitates presidentialism throughout the region since the process of candidate nomination is less competitive than it otherwise could be. ${ }^{17}$ The dwindling popularity of these presidential-style regimes seems to have two effects for peace. First, in Latin America we observe unanticipated situations where domestic insurgencies emerge under democratic rule, as has been the case in recently in Mexico, Colombia, and Peru, and even earlier in Uruguay. This means that when these nations allocated resources to combat domestic upheavals and transnational threats, this decision also raised the cost of fighting one another, thus deterring possible confrontations. A more feasible possibility might be that the relative autonomy of elected leaders may undermine their own capacity to rally enough support to fight an external war. Hence, when democracies do not fight throughout Latin America, they do so for reasons other than those suggested by the democratic peace literature. Latin nations do not fight each other as often as other developing countries because of the precarious state of democracy in the region, a situation that promotes a great deal of popular discontent and mobilization, as witnessed in Mexico today. An added consideration is that both democracies and authoritarian regimes have to devote a tremendous amount of their political capital to 
promote national development and alleviate the political pressures mounting from the persistent income inequality throughout the region. In this context, interstate wars are perceived as undermining development efforts or supporting generations of unpopular political elites and therefore as contributing to the likelihood of a more explosive domestic situation, resulting not just in civil wars but in some 147 military coups between 1900 and 2000. In fact, after a rigorous analysis of state performance and popular disenchantment, one scholar concludes that "the premature dismissal of elected presidents was due in substantial part to the region's lackluster economic performance." 18 Therefore, both democracies and authoritarians have incentives to avoid wars at all cost in Latin America.

Liberal social scientists consider that the relative prosperity and interdependence brought about by trade constitute a second explanation to sustainable peace. Proponents of this argument claim that the benefits of trade raise the cost of fighting. As Polachek and Seiglie correctly point out, the "peace through trade" hypothesis was popularized by Keynes's critique of the terms of the Treaty of Versailles during the interwar period. ${ }^{19}$ Following Keynes, many social scientists have argued that trade density among nations increases the motivation of state actors to cooperate since the benefits of trade have a spillover effect into other issues. The end result is that trading partners find themselves in a situation of "complex interdependence" that encourages diplomatic solutions to bilateral disputes - witness the case of U.S.-Mexican bilateral relations. $^{20}$

In contrast, I would argue that the evidence supporting the "peace through trade" argument is hazy with respect to Latin America. The main shortcomings of this approach are insufficient covariation and inversed causal direction. Concerning the latter, in order to argue that trade causes peace in the region we must first demonstrate that there is a change in the pattern of trade variability preceding periods of peace. In the Latin American case this level of testing presents a problem because the density of bilateral trade among nations is currently low and has remained so for much of the last four decades. Most Latin nations diversify their dependencies by trading with Europe, the United States, and lately increasingly with the Far East before they trade with each other. This is true even with nations signatory to any of the regional trading regimes. According to data from USAID, in 2005 the value of total Brazilian exports to the United States amounted to \$11 million more than to MERCOSUR, the Southern Cone Common Market to which Brazil is one of the signatories. ${ }^{21}$ Moreover, the degree of causality between trade and peace is weak. As has been persuasively argued, in any robust causal relation variables must follow a causal direction that clearly demonstrates that the causal variable (in this case trade) precedes the dependent variable (peace). ${ }^{22}$ But as I and others have argued, in Latin America, this direction is inversed. ${ }^{23}$ Moreover, since peaceful conditions seem to be a constant feature, the trade volume alone cannot explain them. In addition, as the Brazilian data persuasively shows, the pattern of trade between Latin nations and extra-hemispheric partners is always more robust than with neighboring countries. In short, the peace through trade argument in Latin America is spurious.

In the next section of this article, I argue that another variable - one that might sustain the relative peace experienced by Latin nations during the postwar years - is transnationalism. The perception of transnational threats encourages policy coordination efforts against common enemies and reduces misperceptions among potential adversaries; thus even countries considered traditional rivals face no other alternative than to cooperate. This was the case, for instance, among Brazil, Argentina, and Uruguay, countries with variable political systems, contentious issues, and low trade density among them, but where peace reigns. The conspicuous absence of war is also evident in such traditional adversaries as Mexico and Guatemala or Argentina and Chile. I argue that during the latter part of the twentieth century, there has been a explosion of three major sequential and overlapping transnational threats in Latin America: insurgencies, drug trafficking, and crime.

\section{Transnationalism and dyadic peace}

Before I discuss how transnationalism and peace are correlated, I briefly assess the extent to which these transnational processes present a threat to the hemisphere's regional security. It is important to note that there have been two fundamental shifts in the nature of the political perils in Latin America during recent decades. During the Cold War, the United States and Latin America institutionalized the principles embodied in the Monroe Doctrine when they agreed to sign the Rio Treaty. Thereafter, the deterrence brought about by this and other accords coupled with the spillover social effects of the Cuban revolution fostered an environment in which Latin American elites, particularly the military, perceived their role as primarily guardian of domestic political order. Castro's effort to divert international menace from his revolutions by promising to support revolutionary guerrillas through the continent fueled the perception that the main danger undermining the political climate necessary to push economic development came not from other neighboring military establishments but rather from insurgencies. These fears triggered comprehensive covert counterinsurgency programs, such as Operation Condor, which involved joint military forces from throughout Latin America and the United States. ${ }^{24}$

One of the consequences of the rise of bipolarity for Latin America was a departure from the traditional role of armed forces throughout the region. In almost every country, the military was transformed overnight from a force to guard the territorial integrity of the nation-state against external adversaries to one of carrying out social demobilization decrees to preserve the function of the state as an arena of elite interest intermediation. This first major mission shift is important for the preservation of peace in the region because it connotes that the training, arms procurements, and the strategic framework of the military was retooled to meet a different adversary, one that was domestically rooted. ${ }^{25}$ Coincidentally, the shifting involvement also entailed the emergence of multiple inter-American institutions with 
the intrinsic purpose of promoting the perception of a collective domestic threat and the socialization of military officers from the hemisphere.

One such institution, the Washington-based Inter-American Defense Board, coordinates military training and oversight in the Americas. ${ }^{26}$ Lately, the infusion of drug trafficking activities, organized crime, and gang violence, among other transnational perils, seem to have produced a second transformation in the mission of hemispheric institutions, as well as in the minds of military planners in this Organization of American States (OAS) agency after the downfall of communism and the resulting peace accords in Central America. A content analysis of the recommendations and discussion topics in each of the six naval conferences sponsored by the Inter-American Defense Board between 1990 and 2000 reveals an overwhelming concern with the threats posed by illicit transnational activities and resolution after resolution committing navy forces to coordination and cooperation schemes to combat this rising threat. ${ }^{27}$ This finding is also corroborated by an examination of the curriculum for the 2005-2006 class, hosted by the Board. Modules in crisis management, peace and diplomacy, assessment of transnational threats, and conflict resolution dominate much of the teaching. In short, after 1948, several mechanisms and institutions were developed to sustain the inter-military collaboration regime in Latin America. ${ }^{28}$ At the same time, these institutions buttressed a perception that the real threat to democracy and social well-being emanates from the proliferation of non-state transnational actors.

The recognition that transnational violence poses a major threat to the hemisphere's security was officially articulated in a 2003 OAS security conference held in Mexico City, where the various elements of nontraditional security threats were framed as "the human security paradigm." In this and subsequent meetings officials proposed a comprehensive new collaborative framework among military establishments and between police personnel and civil society to mitigate these illicit activities. At the 2003 OAS meeting, the intergovernmental Committee on Hemisphere Security was institutionalized to assess the functions of hemispheric collective security instruments for the peaceful settlement of disputes as well as new security mechanisms necessary to bear nontraditional transnational security threats. ${ }^{29}$ Just a year later, the ministers of defense convened in Quito, Ecuador, at the Sixth Conference of Ministers of Defense of the Americas. Among other resolutions, the defense ministers agreed to strengthen existing ties among inter-American security conventions, increase the interoperability of the region's armed and public security forces, collaborate in training, share information, and intensify intergovernmental exchange and coordination..$^{30}$

The list of declaration, conventions, and public statements in support of the menacing threats from the new transnationalism is endless. ${ }^{31}$ The point is that the evidence supports the assertion that at the end of the Cold War, the failure of neoliberalist policies to meet rising expectations throughout the region and bridge the income gap between rich and poor seems to have contributed to the proliferation of multiple informal activities, which are perceived as the most urgent threat to national security by officials throughout the hemisphere. ${ }^{32}$ This imminent shift of perception and conceptualization of national security is sustaining the long peace in the hemisphere today, for it has reframed national security to prioritize transnational activities. The emergence of new nontraditional threats poses a common enemy to the state and diverts attention from interstate conflicts. In addition, these activities, by their very nature, require collaboration across nations at multiple levels. Today, Latin states recognize that they cannot tackle the issue of drug trafficking without examining migration and gang violence, and the magnitude and scope of these activities raises the cost of fighting a conventional war. Various hemispheric collaborative arrangements seem necessary to cope with the transnational and multidimensional aspects of violence in the region today. These regimes are also fostering confidence building measures which ultimately guarantee dyadic peace in the region.

After examining the evidence from the Latin American experience, the question remains as to why transnationalism has not produced similar effects elsewhere in the developing world. Here are few assertions. First, throughout the developing world, and to some extent even in Europe, transnational relations involve an element of ethnic conflicts and claims simply not seen in Latin America. Ethnic claims usually end in violence because they involve a historical tradition of oppression that undermines trust among ethnic groups and exacerbates conditions of violence. Moreover, international organizations and institutions are simply not equipped to resolve interethnic conflicts. More often than not, the mission of these institutions has been to contain escalating interstate confrontations. The effective role that the InterAmerican Defense Board is fostering to build confidence among Latin military officials would be severely impaired in Africa or the Middle East. Last, the historical presence of the United States in Latin America has no parallel in other developing regions. As I discussed earlier, the United States and its inter-American agencies and institutions have facilitated and supported the new role of the military in the region as guardians against transnational threats and violence. In short, with respect to war and peace, Latin America may present a deviant case.

Conclusion

This article shows how the shifting nature of transnational threats in the Americas contributes to sustaining the so-called long peace in the region. After scrutinizing various contending peace perspectives, it demonstrates how the effects of transnational threats changed security priorities in the hemisphere. The multidimensional scope of transnational illicit activities has fostered state cooperation as a result of the numerous collaborative arrangements, exchange of communication, and policy coordination developed by the institutions, and conventions devised to mitigate the effects of transnational threats. The effect of this Inter-American security 
regime is paradoxical. While Latin America has experienced its share of revolutions, insurgencies, and domestic violence, the region continues to be one of the most peaceful in the developing world.

Notes

Enrique S. Pumar is Associate Professor of Sociology at The Catholic University of America, Washington, DC. He may be reached at pumar@cua.edu. An earlier version of this article was presented at the 77th Annual Meeting of the Eastern Sociological Society Meeting in Philadelphia, March 15-18, 2007. While the usual disclaimer applies, I thank Jurgen Brauer, J. Paul Dunne, and Howard Lune for useful comments and my dear friend Carlos Seiglie for suggesting I work on the topic.

\section{UNDP (2005, Table 1).}

2. These two cases are the territorial disputes between Peru and Ecuador leading to clashes in 1941, 1981, and 1995, and the "soccer war" between El Salvador and Honduras. I do not include the Malvinas war because it engaged Argentina with Great Britain, an outside country.

3. The within-case comparative approach is a take-off from Juan Linz' seminal work, "Within Nation Differences and Comparisons: The Eight Spains" (Linz and de Miguel, 1966). Within-case comparisons examine variations among the different components of a case-study. With regards to this article, I apply the method to compare different trends within the Latin American case.

4. Hass (1980).

5. Hobbes (1931, pp. 75-77).

6. Polachek and Seiglie (2007). Also see the articles by Polachek and by Pantsios in this issue of the journal as well as that by Bhattacharya and Thomakos.

7. For a comprehensive review of conflict and peace studies, see Cashman (1993).

8. Schmookler (1984, particularly pp. 161-167).

9. Holsti (1987).

10. Schelling (1984).

11. Axelrod (1977).

\section{Waltz (1979); Gilpin (1981); Modelski (1987)}

13. See, e.g., Katznelson and Prewitt (1979).

14. Colombia (1999).

15. Russett (1993, p. 11).

16. See the empirical data from Martin (2006) and Mares (2000).

17. Carey (2003, p. 18).

18. Smith (2005, p. 332).

19. Polachek and Seiglie (2007).

20. Keohane and Nye (2000, pp. 718-731).

\section{USAID (2007).}

22. Stinchcombe (1968, pp. 32-35).

23. See Pumar (1990); Shafer (1988); Martin (2006); Mares (2000); Bailey and Dammert (2005). Many pundits involved in implementing development strategies argue that security was a necessary precursor of trade and development. Their point is that trade and development have a destabilizing effect on states already weak, thus necessitating security arrangements (see, e.g., Shafer, 1988, pp. 80-82).

24. McSherry (2005).

25. For a study of insurgencies and counterinsurgency policies in Latin America, see Kohl and Litt (1974).

26. In the welcome letter of the Circle of Friends, a support organization for spouses of military officers sponsored by the Inter-American Defense Board, the role of this group is described to be "a place to share your ideas and cultural traditions. We are here to provide support, information, and above all long-lasting ties of friendship." In addition, the web site of the Board describes the mission of this institution to be "an international committee of nationally appointed defense officials, who develop collaborative approaches on common defense and security issues facing the Americas." See http://www.jid.org/index.php?lang=en. 


\section{See IADB.}

28. One such illustration of inter-military security collaboration can be found in Operation Condor (see McSherry, 2005).

\section{OAS (2003)}

\section{U.S. Department of State (2004).}

31. According to the latest annual report from the U.N. Office on Drug and Crime, the murder rate in the Caribbean is the highest in the world. Moreover, the crime rate is tied to the volume of drug trafficking throughout the region. Finally, the report concludes, the elevated crime rate is undermining growth, threatening human welfare, and impeding social development (UNODC, 2007). In the rest of Latin America, according to an Inter-American Development Bank report, violent crime cost an alarming 14.2 percent of GDP in 1999 (International Herald Tribute, 2006).

32. Bailey and Dammert (2005).

\section{References}

Axelrod, R. 1977. The Complexity of Cooperation. Princeton, NJ: Princeton University Press.

Bailey, J. and L. Dammert. 2005. Public Security and Police Reform in the Americas. Pittsburgh, PA: University of Pittsburgh Press.

Carey, J.M. 2003. "Presidentialism and Representative Institutions," pp. 11-42 in J. Dominguez and M. Shifter, eds. Constructing Democratic Governance in Latin America. 2nd edition. Baltimore, MD: Johns Hopkins University Press.

Cashman, G. 1993. What Causes War? New York: Lexington Books.

Colombia. 1999. Colombia: Plan for Peace, Prosperity, and the Strengthening of the State. Bogota, Colombia: Presidency of the Republic. See U.S. Institute of Peace: http://www.usip.org/library/pa/colombia/adddoc/plan_colombia_101999.html

Dilthey, W. 1962. Patterns and Meaning in History. New York: Harper and Row.

Gilpin, R. 1981. War and Change in World Politics. Cambridge, UK: Cambridge University Press.

Hass, E. 1980. "Why Collaborate? Issue-Linkage and International Regimes.” World Politics Vol. 32, No. 2, pp. 207-243.

Hobbes, T. 1931. Leviathan. London: J.M. Dent and Sons.

Holsti, O. 1987. "Theories of Crises Decision-Making," pp. 244-281 in P. Viotti and M. Kauppi, eds. International Relations Theory. NewYork: Macmillan.

[IADB] Inter-American Defense Board. http://www.jid.org.

International Herald Tribune. "Crime Hurts Latin America GDP.” Online edition. See http://www.iht.com/articles/2006/10/17/business/crime.php.

Katznelson, I. and K. Prewitt. 1979. "Constitutionalism, Class, and the Limits of Choice in U.S. Foreign Policy" pp. 25-40 in R. Fagen, ed. Capitalism and the State in U.S.-Latin American Relations. Stanford, CA: Stanford University Press. Keohane, R.O. and J.S. Nye, Jr. 2000. "Realism and Complex Interdependence," pp. 718-731 in A. Linklater, ed. International Relations. Critical Concepts in Political Sciences. New York: Routledge.

Kohl, J. and J. Litt. 1974. Urban Guerrilla Warfare in Latin America. Cambridge, MA: The MIT Press.

Linz, J. and A. de Miguel. 1966. "Within Nation Differences and Comparisons: The Eight Spains," pp. 267-319 in R.L. Merrit and S. Rokkan, eds. Comparing Nations. New Haven, CT: Yale University Press.

Mares, D. 2000. "Securing Peace in the Americas in the Next Decade," pp. 35-48 in J. Dominguez, ed. The Future of Inter-American Relations. New York: Routledge. Martin, F.E. 2006. Militarist Peace in South America. Conditions for War and Peace New York: Palgrave.

McSherry, P.J. 2005. Predatory States. Operation Condor and Covert War in Latin America. Lanham, UK: Rowman and Littlefield.

Modelski, G. 1987. Long Cycles in World Politics. Seattle: University of Washington Press.

[OAS] Organization of American States. 2003. Declaration of Security in the Americas.

Polachek, S.W. and C. Seiglie. 2007. "Trade, Peace and Democracy: An Analysis of Dyadic Dispute," pp. 1017-1073 in T. Sandler and K. Hartley, eds. Handbook of Defense Economics. Vol. 2. Amsterdam: Elsevier.

Pumar, E.S. 1990. "Recent Trends in U.S. Economic Policy Towards Latin America," pp. 403-421 in M. Mtewa, ed. International Development and Alternative Futures: The Coming Challenges." New Delhi: Allied Press.

Russett, B. 1993. Grasping the Democratic Peace. Princeton, NJ: Princeton University Press.

Shafer, D.M. 1988. Deadly Paradigms. The Failure of U.S. Counterinsurgency Policy. Princeton, NJ: Princeton University Press.

Schelling, T. 1984. "What Is Game Theory?” pp. 312-242 in T. Schelling. Choice and Consequence. Cambridge, MA: Harvard University Press.

Schmookler, A.B. 1984. The Parable of the Tribes. Boston: Houghton Mifflin.

Smith, P.H. 2005. Democracy in Latin America. New York: Oxford University Press. Stinchcombe, A.L. 1968. Constructing Social Theories. New York: Harcourt, Brace and World.

[UNDP] United Nations Development Program. 2006. Human Development Report 2005. http://hdr.undp.org/reports/global/2005/.

[UNODC] United Nations Office on Drugs and Crime. 2007. UNODC Annual Report 2007. http://www.unodc.org/unodc/annual_report_2007.html. 
[USAID] United States Agency for International Development. 2007. Latin America and the Caribbean. Development Statistics. http://qesdb.usaid.gov/lac/index.html.

United States Department of State. 2004. Sixth Conference of the Ministers of Defense of the Americas: Declaration of Quito. http://www.state.gov/p/wha/rls/71006.htm.

Waltz, K. 1979. The Theory of International Relations. Boston. Addison-Wesley. 